\title{
Desmutagenicity of Commercial Cheese against the Trp-P1-induced Mutagenicity to Streptomycin-dependent Strain SD 510 of Salmonella typhimurium TA 98
}

\author{
Masako YAMADA, Yuji NAKAZAWA* \\ and Akiyoshi HOSONO** \\ Kyoritsu Women's College, Chiyoda-ku, Tokyo 101-8433 \\ * Course of Human and Cultural Research, Kyoritsu Women's University, \\ Chíyoda-ku, Tokyo 101-8433 \\ ** Faculty of Agriculture, Shinshu University, Minamiminowa-mura, \\ Nagano-ken 399-4598
}

(Received October 24, 1997)

\begin{abstract}
Desmutagenicity of various types of commercial ripened cheese against the mutagenicity of an amino acid pyrolysate, Trp-P1, using the streptomycin-dependent strain (SD510) of Salmonella typhimurium TA98, was studied. All kinds of cheese showed high desmutagenicity and were dose-dependent. The desmutagenicity of Camembert, Blue, Emmental, Gruyère and Pont-l'Evèque cheeses using secondary starter were higher than those of Cheddar, Gouda, Edam and Parmesan cheeses using only lactic acid bacteria as starter. Especial ly among the cheeses tested, the desmutagenicity of Camembert and Blue cheeses showed a rapid increase with increase in the amount of cheese suspensions, and reached a maximum of $100 \%$ at 150 and $250 \mu l$ of cheese suspensions, respectively.
\end{abstract}

Anim. Sci. Technol. (Jpn.) 69 (4) : 359-364, 1998

Key words : Desmutagenicity, Ames test, Trp-P 1, Cheese

Dietary inhibitions of mutagenesis and carcinogenesis are of particular interest because they may be useful for human cancer prevention. Lactic acid bacteria and some fermented milk products with lactic acid bacteria possess therapeutic, anticarcinogenic or desmutagenic properties ${ }^{3,7,9,21,22)}$. In recent years, much attention has been paid to desmutagenic properties of fermented milk products. Hosono and coworkers ${ }^{10,11,14,25-27,32)}$ reported that lactic acid bacteria and fermented milk possess a desmutagenic activity against the mutagenicity of amino acid pyrolyzates, potential chemical carcinogens and food-related mutagens.

Cheese is also a popular dairy product. The high nutritional value of cheese is made up of the nutrients of the milk and the metabolites

Salmonella typhimurium TA 98 加ら造成されたストレプトマイシン依存株 SD 510 の Trp-P1の変異原性に対す

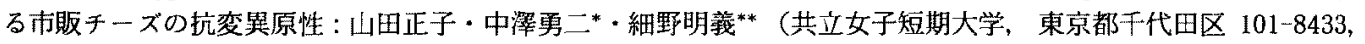

*共立女子大学大学院, 東京都干代田区 101-8433, ** 信州大学㖘学部, 長野県南箕輪村 399-4598) 
produced during ripening by lactic acid bacteria, some mould or other bacteria in cheese manufacture. However, different types of cheese may have their respective physiological properties. We perviously reported the inhibitory activity of Camembert cheese against the mutagenicity of 3-amino-1,4-dimethyl$5 H$-pyrido $[4,3-b]$ indole $(\operatorname{Trp}-\mathrm{P} 1)^{31)}$. This findings is very interesting because many of the physiological properties are unknown and only a few reports were published ${ }^{16)}$ regarding desmutagenic properties of cheeses.

The aim of this study was to investigate the desmutagenic effects of various types of cheese against Trp-P1 using the test strain SD 510, a streptomycin-dependent strain of Salmonella typhimurium TA $98^{12)}$.

\section{Materials and Methods}

\section{Materials}

The following 9 kinds of cheeses, purchased from markets in Tokyo, were used in this study : Camembert and Blue cheeses as mouldripened cheeses; Cheddar, Gouda, Edam and Parmesan cheeses as lactic acid bacteriaripened cheeses; Emmental and Gruyère cheeses as propionic acid bacteria-ripened cheeses ; and Pont - l'Eveque cheese as Brevibacterium-ripened cheese. As the mutagen, the amino acid pyrolysate, Trp-P 1, was used and purchased from Wako Pure Chemical Co., Ltd, Osaka, Japan.

\section{Bacterial cultures}

Streptomycin-dependent strain (SD 510) of $S$. typhimurium TA98 ${ }^{12}$ used throughout this study was cultivated in SM 20 medium at $37^{\circ} \mathrm{C}$. The SM 20 medium contained $25 \mathrm{~g}$ of Oxoid Nutrient Broth No. 2 (OX-medium) and $20 \mathrm{mg}$ streptomycin in $1,000 \mathrm{~m} l$ of pure water.

\section{Assay for desmutagenicity}

Desmutagenicity was estimated by measuring the decrease in mutation induced by Trp$P 1$ and carried out according to the method of Ames $e t a l .^{2\rangle}$. In brief, a solution containing $150 \mu l$ of Trp-P 1 in distilled water $(2 \mathrm{mg} / \mathrm{m} l)$ was mixed with $350 \mu l$ of cheese suspension, which was prepared by homogenizing of $2 \mathrm{~g}$ of whole cheese mixture with $98 \mathrm{~m} l$ of distilled water for $15 \mathrm{~min}$ using a homogenizer. The mixture was preincubated at $37^{\circ} \mathrm{C}$ for $60 \mathrm{~min}$. After which, the mixture was sterilized by filtering the extract through a membrane filter $(0.45 \mu \mathrm{m})$ (Fuji Film Co., Tokyo, Japan).

The test strain SD510 was grown in SM 20 medium overnight in a shaking water bath at $37^{\circ} \mathrm{C}$. The culture was diluted 1,000 fold with $1 / 15 \mathrm{M}$ phosphate buffer ( $\mathrm{pH} 6.98$ ) and $100 \mu l$ of the diluted culture was laid on a plate of the OX-agar medium. Then, $40 \mu l$ aliquots of the filtered cheese suspension containing Trp-P1 were applied to a sterile $8 \mathrm{~mm}$ paper disk which was placed on the center of the OX-agar medium, and incubated at $37^{\circ} \mathrm{C}$ for $48 \mathrm{~h}$. In case of the positive control, distilled water was used instead of the cheese suspension, while the negative control had no Trp-P1. All assays were repeated at least twice, with triplicates each time.

The desmutagenicity was estimated by measuring the decrease in mutation induced by the mutagen and expressed as percentage inhibition. Desmutagenicity was quantified in terms of inhibition percentage of mutagenicity $(\mathrm{PI})$ and calculated :

$$
\mathrm{PI}(\%)=100-(\mathrm{A}-\mathrm{C} / \mathrm{B}-\mathrm{C}) \times 100 \text {, }
$$

where $A$ is the number of revertants of test plate, $B$ is the number of revertants of the positive control and $\mathrm{C}$ is the number of spontaneous revertants of the negative control that had no Trp-P 1.

\section{Chemical analyses of cheese}

$\mathrm{pH}$ and acidity as lactic acid of cheese samples were analyzed by standard methods ${ }^{23)}$. Water soluble nitrogen and total $\mathrm{N}$ were determinated by the Kjeldahl method and calculated ${ }^{24)}$ :

Ripening index (\%)

$$
=(\text { Water soluble } \mathrm{N} / \text { Total } \mathrm{N}) \times 100
$$

All the assays were repeated three times. 


\section{Results and Discussion}

\section{Analysis of general compositions}

The cheeses were analyzed for general compositions : $\mathrm{pH}$, lactic acidity and water soluble $\mathrm{N}$ as \% of total $\mathrm{N}$. The results obtained are given in Table 1. These values were suitable and were widely accepted for consideration of each cheeses composition ${ }^{8,18,20)}$, The $\mathrm{pH}$ and water soluble $\mathrm{N}$ as \% of total $\mathrm{N}$ of Camembert, Blue and Pont-l'Evèque cheeses were higher than those of other cheeses : 6.60 and $77.4 \%$, 6.64 and $51.3 \%$, and 7.65 and $63.3 \%$, respectively. The high values were due to proteolysis by moulds such as Penicillium camemberti ${ }^{8)}$ for Camembert cheese and Pen. roquefort $i^{8)}$ for Blue cheese, or Brevibacterium ${ }^{28)}$ for Pontl'Evèque cheese with strong proteolytic activity, and proteolysis of casein with the formation of some peptides and amino acids.

\section{Desmutagenicity of cheeses}

Changes in the desmutagenicity of cheeses to Trp-P 1 on S. typhimurium SD 510 by the amount of cheese suspensions are shown in Fig. 1. In order to establish the desmutagenic properties of the cheeses, cheese suspensions at a range of $50,150,250$ and $350 \mu l$, were examined. All kinds of cheese exhibited high

Table 1. General characteristics of cheeses $(n=4)$

\begin{tabular}{|c|c|c|c|c|c|c|c|c|c|}
\hline & \multicolumn{2}{|c|}{$\begin{array}{l}\text { Mould-ripened } \\
\text { cheeses }\end{array}$} & \multicolumn{4}{|c|}{ Lactic acid bacteria-ripened cheeses } & \multicolumn{2}{|c|}{$\begin{array}{l}\text { Propionic acid } \\
\text { bacteria- } \\
\text { ripened cheeses }\end{array}$} & \multirow{2}{*}{$\begin{array}{c}\text { Brevibacte- } \\
\text { rum-ripened } \\
\text { cheese } \\
\begin{array}{c}\text { Pont-l'Evèque } \\
\text { cheese }\end{array}\end{array}$} \\
\hline & $\begin{array}{l}\text { Camembert } \\
\text { cheese }\end{array}$ & $\begin{array}{l}\text { Blue } \\
\text { cheese }\end{array}$ & $\begin{array}{l}\text { Cheddar } \\
\text { cheese }\end{array}$ & $\begin{array}{l}\text { Gouda } \\
\text { cheese }\end{array}$ & $\begin{array}{l}\text { Edam } \\
\text { cheese }\end{array}$ & $\begin{array}{l}\text { Parmesan } \\
\text { cheese }\end{array}$ & $\begin{array}{c}\text { Emmental } \\
\text { cheese }\end{array}$ & $\begin{array}{l}\text { Gruyère } \\
\text { cheese }\end{array}$ & \\
\hline $\mathrm{pH}$ & 6.60 & 6.64 & 5. 48 & 5.69 & 5.04 & 5.54 & 5.28 & 5.26 & 7.65 \\
\hline Lactic acidity $(\%)$ & 0.84 & 1.28 & 1.02 & 1.16 & 1.82 & 1.72 & 1.11 & 1.07 & 0.76 \\
\hline Ripening index $(\%)^{*}$ & 77.4 & 51.3 & 27.1 & 28.9 & 27.3 & 24.5 & 26.5 & 30.2 & 63.3 \\
\hline
\end{tabular}

* Ripening index $(\%)$ means water soluble nitrogen $(\mathrm{N})$ as \% of Total N.
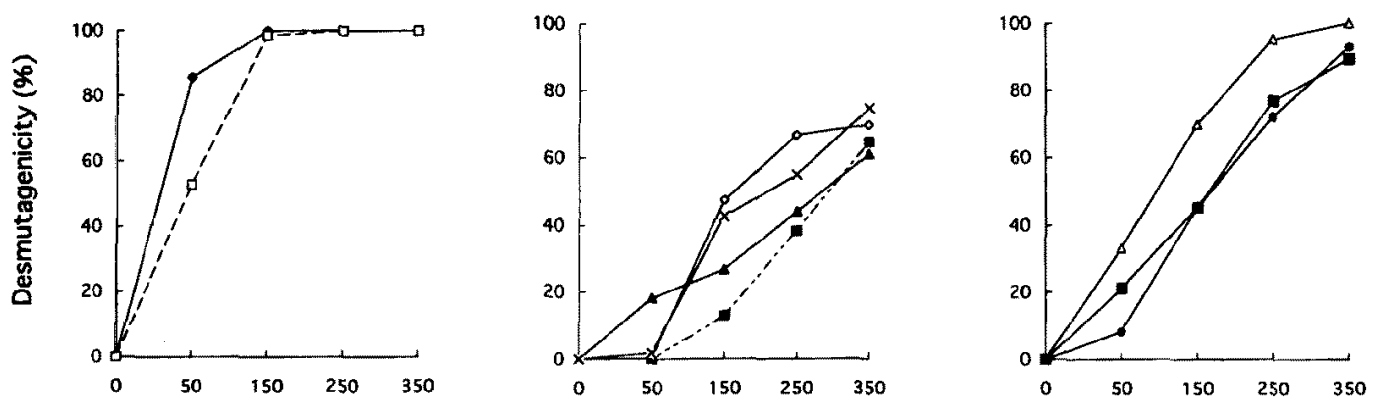

Amount of cheese suspensions $(\mu \mid)$

Mould-ripened cheeses:

$\longrightarrow$ Camembert cheese,

- $-\cdots-$ Blue cheese
Lactic acid bacteria-ripened cheeses;

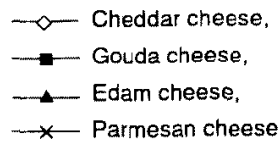

Propionic acid bacteria- and Brevibacterium -ripened cheeses;

$\rightarrow$ Emmental cheese.

$\triangle-$ Gruyere cheese,

- Pont-l'Eveque cheese

Fig. 1. Dose response of desmutagenicity of cheese suspensions to Trp-P1 on Salmonella typhimurium SD510 $(\mathrm{n}=4)$. 
and dose-related desmutagenicity. Especial1y, Camembert and Blue cheeses showed rapid increase in desmutagenicity with increase in the amount of cheese suspensions, and reached a maximum of $100 \%$ with cheese suspensions of only a 150 and a $250 \mu l$, respectively. The desmutagenicity of other cheeses showed gradual increase with increasing amount of cheese suspensions, and a maximum with $350 \mu \mathrm{l}$ of cheese suspension. The scores of the others were as follows : Cheddar cheese $69.8 \%$, Gouda cheese $64.6 \%$, Edam cheese $61.1 \%$, Parmesan cheese $74.7 \%$, Emmental cheese $89.3 \%$, Gruyère cheese $100.0 \%$ and Pont-1'Evèque cheese $93.0 \%$.

Camembert, Blue, Emmental, Gruyère and Pont - l'Evèque cheeses exhibited higher desmutagenic effects than those of Cheddar, Gouda, Edam and Parmesan cheeses. These findings are likely to have some effects on the symbiotic actions by mixed strain starters both lactic acid bacteria and secondary starter. The main reason for the ripening of cheeses by the mixed strain starters is their difference in metabolites and ripening conditions. The desmutagenicity and ripening of cheeses are considered rather a complicated phenomenon, both experimentally and theoritically. Hosono et al..$^{11,14)}$ and Nadathur et al. ${ }^{19)}$ reported the desmutagenicity of lactic acid bacteria or cultured milk with lactic acid bacteria, and also the desmutagenicity of lactic acid bacteria isolated from cheese ${ }^{6,32)}$; the lactic acid bacteria such as Lactococcus lactis ssp. lactis, $L c$. lactis ssp. cremoris, Lc. lactis ssp. diacetylactis, Str. thermophilus and Lactobacillus helveticus, are usually being used for cheesemaking. More over, Hosono et al. reported that the slimy substance consisting of sticky materials and cells of Brevibacterium linens exhibited remarkable antimutagenic activity towards Trp$\mathrm{P} 1$ and 3-amino-1-methyl-5 $H$-pyrido $[4,3-b]$ indole (Trp-P-2) $)^{15)}$. Vorojeva et al. reported that dialysates of the cells of propionic acid bacteria contained several kinds of desmutagenic substances with different molecular weights $^{30)}$. From these findings, high desmutagenicity of cheeses could appear to influence synergistic effects between secondary starter and lactic acid bacteria.

On the other hand, the higher desmutagenicity of Camembert, Blue and Pontl'Evèque cheeses could be correlated to higher value of water soluble $\mathrm{N}$ as \% of total $\mathrm{N}$ as shown in Table 1. Such degradation might be affected by the enzymes released from bacteria such as lactic acid bacteria as starter, propionic acid bacteria, Brevibacterium linens, yeasts, and moulds like Pen. roqueforti and Pen. candidum. van Boekel et al. ${ }^{29)}$ reported on desmutagenicity of casein against mutagenicity induced by benzo $[a]$ pyrene $(\mathrm{B}[a] \mathrm{P}), N$-metylnitrosourea and nitrosated 4-chloroindole, and pepsinhydrolysed casein against mutagenicity induced by sodium azide and 4-nitroquinoline-1oxide (4NQO) to $S$. typhimurium TA 100 and Escherichia coli $\mathrm{K}-12-343$. Bosselaers et al. ${ }^{5)}$ have shown that casein, its pepsin hydrolysis products have a protective effect against certain genotoxic compounds, where as other milk proteins like whey protein, $\beta$-lactoglobulin had no protective action. More over, Abdelali et al. ${ }^{1)}$ reported that the desmutagenic potential of casein increased with pepsin hydrolysis was due to the peptides formed, which interact with the mutagens. Nevertheless ripening period of Cheddar, Gouda, Edam and Parmesan cheeses were longer than that of other cheeses, which have low water soluble $N$ as $\%$ of total N. In addition, since Cheddar, Gouda, Edam and Parmesan cheeses showed desmutagenic activity, the desmutagenicity of these cheeses could be partly due to the casein. The desmutagenic properties of casein, being a major constituent of milk products, have been demonstrated in salmonella/microsome test for nitroso compounds ${ }^{4,19,29)}$ and on pepper extracts $^{13)}$. Thus the desmutagenicity of cheeses could be attributed to various microorganisms, proteinases and other related enzymes produced by micro-organisms, and 
casein with the formation of low molecular weight peptides and amino acid during ripening of cheese.

In this study, it was confirmed that various types of ripened cheese from markets had the desmutagenicity against the Trp-P1-induced mutagenicity to SD510. This conclusion was supported by the findings, of Lê et al. ${ }^{17)}$ who reported that the risk of breast cancer was found to be positively associated with frequent cheese consumption in a case-control study, and Jongen et al ${ }^{16)}$ who reported the inhibitory potential of Gouda cheese on the mutagenicity generated in feva beans after treatment with nitrite in acidic solution. However, more work has to be done to understand the exact mechanisms involved.

\section{Acknowledgements}

The authors are grateful to the research students in the Lab. of Food Science, Kyoritsu Women's University for their great support and technical assistance.

\section{References}

1) Abdelali $H$, Cassand $P$, Soussotte V, KochBocabeille B, Narbonne JF. Antimutagenicity of components of dairy products. Mutat. Res., $331:$ 133-141. 1995.

2) Ames BN, McCann J, Yamasaki E. Methods for detecting carcinogens and mutagens with the Salmonella/mammalian-microsome mutagenicity test. Mutat. Res., 31 : 347-364. 1975.

3) Ayobo AD, Shahani KM, Dam R, Friend BA. Ion exchange separation of the antitumor com. ponent (s) of yogurt dialyzate. J. Dairy Sci., $65: 2388-2390.1982$.

4) Berg HE, van Boekel MAJS, Jongen WMF. Heating milk: a study of mutagenicity. J. Food Sci., 55 : 1000-1003. 1990.

5) Bosselaers IEM, Caessens PWJR, van Boekel MAJS, Alink GM. Differential effects of milk proteins, BSA and soy protein on $4 \mathrm{NQO}-$ or MNNG-induced SCEs in V 79 cells. Food Chem. Toxic., 32 : 905-909. 1994.

6) Boubekri K, Orta Y. Antimutagenicity of lactic acid bacteria from El-Klila cheese. J. Food Agric., 72 : 397-402. 1996.
7) Fernandes CF, Shahani KM, Amer MA. Therapeutic role of dietary lactobacilli and lactobacilli fermented dairy products. FEMS Microbiol. Rev., $46: 343-356.1987$.

8) Fox PF. Cheese : Chemistry, Physics and Microbiology Volume 2. Chapman \& Hall. USA. 1993.

9) Gilliland SE. Health and nutritional benefits from lactic acid bacteria. FEMS Microbiol. Rev., 87 : 175-188. 1990.

10) Hosoda M, Hashimoto $H$, Morita $H$, Chiba $M$, Hosono A. Antimutagenicity of milk cultured with lactic acid bacteria against $N$-Methyl$N^{\prime}$-Nitro-N-Nitrosoguanidine. J. Dairy Sci., $75:$ 976-981. 1992.

11) Hosono A, Kashina $T$, Kada T. Antimutagenic properties of lactic acid-cultured milk on chemical and fecal mutagens. J. Dairy Sci., 69 : 2237-2242. 1986.

12) Hosono A, Omote E, Izawa $Y$, Tokita F, Kada T. Isolation of spontaneous induced-streptomycin dependent mutants of Salmonella typhimurium TA 98 and TA 100 strains and desmutagenicity tests in vitro of cultured milk. Lebensm.-Wiss.und. - Technol., $19:$ 161-163. 1986.

13) Hosono A, Shashikanth KN, Otani H. Antimutagenic activity of whole casein on the pepper -induced mutagenicity to streptomycin-dependent strain SD510 of Salmonella typhimurium TA 98. J. Dairy Res., 55 : 435-442. 1988.

14) Hosono A, Wardojo R, Otani H. Inhibitory effects of lactic acid bacteria from fermented milk on the mutagenicities of volatile nitrosamines. Agric. Biol. Chem., 54 : 1639-1643. 1990.

15) Hosono A, Yamazaki H, Otani H. Antimutagenicity of slimy susbstance separated from the culture of Brevibacterium linens. Jpn. J. Zootech. Sci., 60:679-685. 1988.

16) Jongen WMF, van Boekel MAJS, Van Broekhoven LW. Inhibitory effect of cheese and some food constituents on mutagenicity generated in vicia faba after treatment with nitrite. Food Chem. Toxic, 25 : 141-145. 1987.

17) Lê MG, Moulton LH, Hill C, Kramar A. Consumption of dairy produce and alcohol in a case-control study of breast cancer. J. Nat. Cancer Inst., 77 : 633-636. 1986.

18) Mair - Waldburg. Handbuch der Käse Volkswirtschafticher Verlag GmbH. Deutschland. 1974 .

19) Nadathur SR, Gould SJ, Bakalinsky AT 


\section{YAMADA, NAKAZAWA and HOSONO}

Antimutagenicity of fermented milk. J. Dairy Sci., 77: 3287-3295. 1994.

20) Nakazawa $Y$, Hosono A. Recent advances in cheese science and technology. Shokuhin Shizai Kenkyukai. Tokyo. 1989.

21) National Dairy Council. Yogurt-its nutritional and health benefits. Dairy Counc. Dig., $61: 1-12.1990$.

22) Reddy GN. Friend BA, Shahani KM, Farmer RE. Antitumor activity of yoghurt components. J. Food Protec., $46:$ 8-11. 1983.

23) Standard methods of analysis of milk and milk products - With commentary - The Pharmaceutical Society of Japan. Tokyo. 1990.

24) Sukegawa K. Nyugyogijutsubinran volume 2. Rakunou Gijutu Fukyukai. Tokyo. 1976.

25) Surono IS, Hosono A. Antimutagenicity of milk cultured with lactic acid bacteria from dadih against mutagenic Terasi. Milchwissenschaft, 51 : 493-497. 1996.

26) Thyagaraja N, Hosono A. Antimutagenicity of lactic acid bacteria from "Idly" against foodrelated mutagens. J. Food Protec, 56 : 10611066. 1993.
27) Thyagaraja N, Hosono A. Binding properties of lactic acid bacteria from "Idly" toward foodborne mutagens. Food Chem. Toxic., 32 : 805809. 1994.

28) Tuckey SL, Sahasrabudhe MR. Studies in the ripening of Limburger cheese. J. Dairy Sci., 40: 1329-1337. 1957.

29) van Boekel MAJS, Weerens CNJM, Holstra A, Scheidtweiler CE, Alink GM. Antimutagenic effects of casein and its digestion products. Food Chem. Toxic., 31 : 731-737. 1993.

30) Vorobjeva LI, Cherdinceva TA, Abilev SK, Vorobjeva NV. Antimutagenicity of propionic acid bacteria. Mutat. Res., 251 : 233-239. 1991.

31) Yamada M, Nakazawa Y, Tsukasaki F, Hosono A. Antimutagenic activity of Camembert cheese on the Trp-P1-induced mutagenicity to Streptomycin-dependent strain SD510 of Salmonella typhimurium TA98. Int. Dairy J. 1998. (in press)

32) Zhang $X B$, Ohta $Y$, Hosono A. Antimutagenicity and binding of lactic acid bacteria from a Chinese cheese to mutagenic pyrolyzates. J. Dairy Sci., $73: 2702-2710.1990$. 